\title{
Josipa JERABEK: Croatian Constitution of 1990, Constitutional Acts of 1991 and International Recognition of the Republic of Croatia
}

\author{
University of Zagreb, Faculty of Law
}

DOI 10.21862/siaa.5.9

\section{Introduction}

After the cold war division on eastern and western block, the world was facing the process of gradual disintegration of communistic regimes in 1980s and 1990s. At the same time, European Community (EC) was on the path of becoming a stronger integration and Croatia was on the way of using its rights and becoming an independent state. In fact, Croatia was facing a brutal aggression launched from Serbia in cooperation with the Yugoslav National Army (YNA) that, despite the lack of any legally or reasonable ground, wanted to establish borders of Great Serbia and in the same time prevent Croatia from becoming an independent state. During 1990s, Croatia suffered severe damages but political and constitutional acts ensured establishment of sovereign, independent and internationally recognized state.

\section{Socialist Federal Republic of Yugoslavia}

Socialist Federal Republic of Yugoslavia (Yugoslavia, SFRY) was a multinational state with federal structure led by the authoritarian communist leader Josip Broz Tito who was also the leader of the only allowed political party called the Communist Party of Yugoslavia. Federation constituted six states: Slovenia, Croatia, Serbia, Bosnia and 
Herzegovina, Montenegro, Macedonia, and two autonomous provinces Vojvodina and Kosovo. Disadvantages in political and ethnical structure were visible for a long time, especially when the national movements in 1970s became stronger showing the failure of utopian idea of Yugoslavian brotherhood and unity. Because of appeared crises, at 1974 the authorities adopted the Constitution of SFRY that have weakened influence of the federal authorities, led to de-etatization, decentralization and gave the republics the right to self-determination that in 1990s enabled republics to exit the Federation and gain independence. ${ }^{1}$

\section{Changes in Croatia}

\subsection{The elections and amendments in $\mathbf{1 9 9 0}$}

The first multiparty elections in Croatia were held in April and May of 1990. Croatian Democratic Union (Hrvatska demokratska zajednica), led by the future Croatian president Franjo Tuđman, was the party that won the elections. On 30 th May 1990, the Parliament of Socialist Republic of Croatia (SRC) was constituted and Franjo Tuđman was elected in Parliament as the president of the Presidency of SRC. On $25^{\text {th }}$ July Parliament adopted the constitutional amendments and from that moment the name of the state was Republic of Croatia. The amendments abolished ideological symbols and names, abolished the Presidency and introduced the function of the President of

\footnotetext{
${ }^{1}$ ČEPULO, Dalibor: Hrvatska pravna povijest u europskom kontekstu od srednjeg vijeka do suvremenog doba [Croatian legal history in the European context from the Middle Ages to modern times]. Zagreb, 2012, Pravni fakultet Sveučilišta u Zagrebu, p. 323., 333., 341.; IBLER, Vladimir: Pravo naroda na samoodređenje i zloupotreba tog prava [The right of the people to self-determination and the abuse of that right]. Politička misao. 1992, vol. 29., no. 2, pp. 67-73.; TOMAC, Zdravko: Jugoslavenski federalizam [Yugoslav federalism]. Politička misao. 1986, vol. 23., no. 3, pp. 4-14.; Silber, Laura - Little, Alan: Smrt Jugoslavije [Death of Yugoslavia]. Opatija, 1996, Otokar Krešovani, p. 8.; CUPEK-HAMILL, Mirjana: Konferencija o miru u Jugoslaviji i raspad jugoslavenske federacije (1991-1992) [Conference on Peace in Yugoslavia and the Disintegration of the Yugoslav Federation (1991-1992)]. Zagreb, 2008, Leykam international, p. 33.; RUDOLF, Davorin: Stvaranje hrvatske države 1991.: ministarska sjećanja [The Creation of the Croatian State in 1991: Ministerial Memories]. Split, 2016, Književni krug, p. 59.; BANAC, Ivo: Historiography of Countries of Eastern Europe: Yugoslavia. Oxford, 1992, Oxford University Press, pp. 1087-1088.
} 
Republic instead, introduced a term minister and a government, and declared that all forms of ownership are equal and equally protected.

\subsection{The Christmas Constitution}

At the end of 1990 Slovenia and Croatia adopted their own republican constitutions, whereby Slovenia set a six-month deadline within which republics have to agree on future regulation of the state. Instead, the Croatian Constitution of $22^{\text {nd }}$ December 1990 did not explicitly set transitional period, but determined that "Croatia remains the part of SRFY until a new agreement or until the Croatian Parliament decides otherwise"2 Later on, because of lack of political will from the Serbian side and unclear Bosnian and Macedonian political stand, it was impossible to reach confederal agreement. Therefore, Croatia and Slovenia adopted a Resolution on the Acceptance of the Procedure for the Disintegration of the SFRY and on the Possible Association to the Alliance of Sovereign Republics. That Resolution set 30 ${ }^{\text {th }}$ June 1991 as a final date for ending a process of dissociation and association. ${ }^{3}$

\subsection{The referendum and Acts of June 1991}

On 19th May 1991, Croatia held a referendum deciding whether Croatia will use its constitutional right and become sovereign state. On the referendum 83,54\% citizens participated, and $93,24 \%$ of them gave positive answer about leaving the Yugoslavia and establishing a sovereign state. ${ }^{4}$

\footnotetext{
${ }^{2}$ Art. 140. Ustava RH, Narodne novine br. 56/1990.; Rezolucija o postupku za razdruženje SFRJ i o mogućem udruživanju u savez suverenih republika, Narodne novine br. 8/1991; Izmjena Ustava XCIX Ustava Republike Slovenije, Uradni list Republike Slovenije (dalje: Uradni list RS), št. 7/1991; Resolucija o predlogu za sporazumno razdružitev Socialistične federativne republike Jugoslavije, Uradni list RS, št. $7 / 1991$.

${ }^{3}$ ČEPULO, op. cit., p. 376.

4 "Frankfurter Randschau" monitored the intensification of conflicts in June and characterized the situation in Croatia as a "Wild west". HR-HDA-1579., 30 Days in Croatia, The political Scene in Croatia, June 1991.; compare with:. MARUšić, Bartul: Pravo na samoodređenje naroda u svjetlu
} 
On $25^{\text {th }}$ June 1991, the Croatian Parliament adopted the Constitutional decision on sovereignty and independence of Republic Croatia and Declaration on the proclamation of the sovereign and independent Republic of Croatia. On the same day, the Parliament enacted the Charter of rights of Serbs and other nationalities in Croatia, by which Croatia guaranteed the right to respect, self-preservation and cultural autonomy to all minorities.

\subsubsection{Constitutional Decision on the sovereignty and independence of Republic of}

\section{Croatia}

Constitutional Decision on the sovereignty and independence of the Republic of Croatia was a historical document passed by the Croatian parliament on $25^{\text {th }}$ June 1991. The decision based on the right to self-determination including the right to dissociation and association with other peoples and states. Other grounds for enacting the Decision were the will expressed on the referendum of $19^{\text {th }}$ May 1991 and the lack of an agreement on future of SFRY. In addition, the Croatian authorities emphasized the fact that the SFRY violated human rights and that it did not act like constitutional and legally regulated state. The Decision of $25^{\text {th }}$ June 1991 declared that Croatia respects equal rights, makes and effort to settle all issues on an equal, democratic and peaceful basis, respects sovereignty and territorial integrity of other states, and is ready to agree with other states on economic, political, defense and other ties. The Decision declared Croatia as a sovereign and independent state that launched a process of dissolution from SFRY as well as the procedure of international recognition. ${ }^{5}$

\footnotetext{
međunarodnopravnih pitanja i disolucije SFRJ [The right to self-determination of the people in the light of international legal issues and the dissolution of the SFRY]. Studia Polensia. 2007, vol. 6., no. 1, p. 72.

${ }^{5}$ Ustavna odluka suverenosti i samostalnosti Republike Hrvatske, Narodne Novine no. 31/1991; Deklaracija o proglašenju suverene i samostalne Republike Hrvatske, Narodne Novine br. 31/1991; Povelja o pravima Srba i drugih nacionalnosti u Republici Hrvatskoj, Narodne Novine br. 31/1991; more in: VUKAS, Budislav: The Process of the Establishment of the Independence of the Republic Croatia from the Perspective of Intenational Law. Rewiev of the Croatian History. 2011, vol. 7., no. 1., p. 17; SMERDEL, Branko: Ustavno uređenje europske Hrvatske [Constitutional organization of European Croatia]. Zagreb, 2013, Narodne novine, pp. 260-262.; Temeljna ustavna listina o samostojnosti i neodvisnosti Republike Slovenije, Uradni list RS, št. 1/1991; Odlok o razglasitvi temeljne ustavne listine o samostojnosti i
} 


\subsubsection{Declaration on the Proclamation of the Sovereign and Independent Republic of}

\section{Croatia}

On $25^{\text {th }}$ June of 1991 , the Croatian Parliament passed the Declaration on the Proclamation of the Sovereign and Independent Republic of Croatia as a document of a political nature that explains proclamation of independence and gives the legalhistorical arguments for independence. Declaration determinates the future Croatian attitude towards other republics and includes the possibility of creating a confederation.

\section{Summer of 1991}

\subsection{War in Slovenia}

After the proclamation of independence on $25^{\text {th }}$ June 1991, YNA launched an attack on Slovenia. According to the Agreement on friendship, cooperation and mutual recognition that Croatia and Slovenia informally established on 20 th January 1990 and formally confirmed on $25^{\text {th }}$ June 1991, Croatia had an obligation to help Slovenia. However, that obligation was not respected because Tuđman realized that attack was nothing but the realization of Serbian-Slovenian alliance. Namely, Slovenia and Serbia had an informal agreement since $24^{\text {th }}$ January 1991 when they arranged the unobstructed Slovenian exit from Yugoslavia. ${ }^{6}$ In fact, the main and only goal of

neodvisnosti Republike Slovenije, Uradni list RS, št. 1/1991; Ustavni amandma k Ustavi Rebublike Slovenije, Uradni list RS, št: 1/1991; Odlok o razglasitvi ustavneg zakona za izvedbo temeljne ustavne listine o samostojnosti i neodvisnosti Republike Slovenije, Uradni list RS, št: 1/1991; Ustavni zakon za izvedbo Temeljne ustavne listine o samostojnosti i neodvisnosti Repubilike Slovenije, Uradni list RS, št. 1/1991; Deklaracija ob neodvisnosti, Uradni list RS, št. 1/1991.

${ }^{6}$ GUŠTIN, Damjan: Slovenija, saveznica Hrvatske tijekom razlaza s jugoslavenskom državom (od „nenačelne koalicije" do raspada vojnog saveza 1989-1991) [Slovenia, an ally of Croatia during the break- 
aggression were Croatian territories and that 10-days war in Slovenia was just a game for the public during which Slovenia supposed to be released from Yugoslavia and Croatia supposed to be dragged into a conflict with discrediting it in the eyes of international community. ${ }^{7}$

\subsection{Internationalization of crisis}

Internationalization of a crisis was seen as only possible solution in accordance with the international and European public law. ${ }^{8}$ Except the embargo on imports of weapon in Croatia, EC send the Observer mission and a delegation called Ministerial troika formed of previous, current, and future representative of the EC Presidency. One of its tasks was to ensure the acceptance of three-month moratorium on implementation of decisions on independence of $25^{\text {th }}$ June $1991 .{ }^{9}$ Accordingly draft of the agreement that Troika already had as a proposed solution, any kind of intervention of YNA would automatically cause international recognition of Croatia and Slovenia. In that way, EC

up with the Yugoslav state (from an "unprincipled coalition" to the break-up of the 1989-1991 military alliance]. Časopis za suvremenu povijest. 2008, vol. 4., no. 1., 2008., pp. 95-98.

7 ŠEKS, Vladimir: 1991 - moja sjećanja na stvaranje Hrvatske i Domovinski rat [1991 - my memories of the creation of Croatia and the Homeland War]. Zagreb, 2015, Večernji list, p. 106.; COHEN, Leonard J.: Broken Bonds: the Disintegration of Yugoslavia. San Francisco, 1993, Westview Press, p. 226; Tomac, Z., The struggle for the Croatian State, Profikon - Zagreb, 1993, p. 87; ZIMMERMAN, Warren: Izvori jedne katastrofe [Sources of a catastrophe]. Zagreb, 1997, Globus, pp. 174-176; compare with:. NAZOR, Ante: Velikosrpska agresija na Hrvatsku 1990 - ih (Republika Hrvatska i Domovinski rat: pregled političkih i vojnih događaja 1990., 1991. - 1995./1998.) [Greater Serbia aggression against Croatia in the 1990s (The Republic Croatia and the Homeland War: Overview of political and military developments 1990, 1991 - 1995/1998)]. Zagreb, 2011, Hrvatski memorijalno-dokumentacijski centar Domovinskog rata, p. 111; MANOLić, Josip: Politika i domovina: moja borba za suverenu i socijalnu Hrvatsku [Politics and Homeland: My Struggle for a Sovereign and Social Croatia]. Zagreb, 2005, Golden Marketing - Tehnička knjiga, p. 162.

${ }^{8}$ BEKIĆ, Andrea: London i Bonn - dva pola politke Europske zajednice prema priznanju Republike Hrvatske 1991. godine [London and Bonn - two poles of European Community policy according to the recognition of the Republic of Croatia in 1991]. Časopis za suvremenu povijest. 2010, vol. 42., no. 2., p. 340.; Despite the awareness of the crisis, violation of human rights and military interventions, European Parliament unequivocally supported the unity of Yugoslavia considering that delimitation of the population was impossible. HR-HDA-1741., f. 95, Europski parlament o situaciji u Jugoslaviji, 22. 3. 1991.

${ }^{9}$ Austrian Foreign Minister had a similar proposal, see in: Mock, Alois: Dossier Balkan i Hrvatska: Ratna agresija u bivšoj Jugoslaviji - perspektive za budućnost [Dossier Balkans and Croatia: War Aggression in the Former Yugoslavia - Perspectives for the Future]. Zagreb, 1998, Hrvatska Sveučilišna Naklada: Hrvatski institut za povijest, p. 68.; LIBAL, Michael: Njemačka politika i jugoslavenska kriza 1991-1992 [German Politics and the Yugoslav Crisis 1991-1992]. Zagreb, 2004, Golden Marketing - Tehnička knjiga, 2004., pp. 32-33. 
would really have an impact on solving a crisis and could exercise its powers, but Troika offered a proposal that was postponing independence and set continuation of negotiations about the new organization of the state. ${ }^{10}$

\subsection{Brioni declaration of 7 July 1991}

At $7^{\text {th }}$ July of 1991 Ministerial Troika held a meeting on Croatian islands Brioni with representatives of republics, Presidency of SFRY, YNA, and Federal executive council. They adopted Directions for the monitoring mission in Yugoslavia and Join declaration of EC Troika and the Parties directly concerned with the Yugoslav Crisis (Brioni Agreement).

The Brioni Agreement supposed to be a mechanism for stopping the war in Slovenia showing the power of EC. At the end, it really announced Slovenian independence. On the other hand, it did not ensured certain future for Croatia, which accepted the Brioni agreement with hope that during the moratorium the world will realize impossibility of survival of Yugoslavia. ${ }^{11}$

\subsection{War in Croatia}

Only day after signing the Brioni agreement, Yugoslav general Kadijević requested a general voluntary mobilization. YNA and Serbia acted completely opposite of the expected way. In fact, they did not respect regulations and commitments, have blocked

\footnotetext{
${ }^{10}$ POFUK, Lujica - MIŠKULIN, Ivica: Europsko vijeće mudraca i okvir optimalne ravnoteže: korijeni, donošenje i posljedice Brijunske deklaracije [European Council of Sages and the framework for optimal balance: roots, adoption and consequences of the Brijuni Declaration]. Pilar. 2014, vol. 9., no. 17-18., p. 53.

${ }^{11}$ NoBILO, Mario: Hrvatski feniks, Dipomatski procesi iza zatvorenih vrata 1990-1997 [Croatian Phoenix, Diplomatic Processes Behind Closed Doors 1990-1997]. Zagreb, 2000, Nakladni zavod Globus, p. 115.; GRANIĆ, Mate: Diplomatska oluja [Diplomatic storm]. Zagreb, 2019, Večernji list, p. 18; On the problem of stereotypes about Croatia and the spread of Serbian propaganda during independence see more in: SKOKO, Božo: Medijska slika Hrvatske 1991. u europskoj javnosti - uloge propagande, stereotipa i odnosa s javnošću [Media image of Croatia in 1991 in the European public - the role of propaganda, stereotypes and public relations]. In: CVIIIÍ, Sandra - ŽEBEC ŠIL, Ivana - BENDRA, Ivan (eds.): Domovinska (i europska) sigurnost: kriza sigurnosti i politike manipuliranja suverenitetom [Homeland (and European) security: security crisis and sovereignty manipulation policies]. Zagreb, 2017, Institut društvenih znanosti Ivo Pilar, Zagreb, pp. 25-38.
} 
the work of the Presidency, attacks on Croatia were even more often and paramilitary and parapolice units of local Serbian inhabitants were openly supported. ${ }^{12}$

From the end of August and during the September, Croatia was involved in undeclared war in which YNA was mostly the main attacker. Until the end of August, Croatia lost control on the huge amount of territories from which the Croatian population was expelled. ${ }^{13}$

Pictures of casualties and damages caused by aggression on Croatia started breaking an irrational myth about equalization of Croatian and Serbian guilt for the war as well as Serbian defence of fascism. EC finally realized the truth about Milošević and his intentions and there was anymore no doubt that Serbia did not want to establish peace but had intention to establish boundaries of a Great Serbia. ${ }^{14}$

\subsection{Carrington conference}

Conference was a conciliation procedure and one of the mechanisms in accordance with the international law with a goal to find a peaceful solution for the crisis. The Conference established arbitration commission also known as Badinter commission. It declared that it will not accept violent and one-sided changes of borders, that the

\footnotetext{
${ }^{12}$ https://daniponosa.hrt.hr/dani-ponosa/51/8-srpnja-1991-potpisana-brijunska-deklaracija [Access on January 10,2022$]$.

${ }^{13}$ HR-HDA-1741, f. 96, Press statement by ambasador Henry Wijnaendts after his visit to eastern Slavonia after the Declaration on Yugoslavia, 17. 8. 1991.; HR-HDA-1741., f. 95, CSCE news relese: Helsinki commission leaders seek CSCE Peacekeeping Force greater Support for Individual Republics, 29. 8. 1991.; Due to a lack of political consensus and public confirmation, WEU has not planned to take action until the EC explicitly requested.; Srebrenica, a Safe Area: Reconstruction, Background, Consequences and Analyses of the Fall of a Safe Area. Amsterdam, 2002, Netherlands Institut voor Oorlogsdocumentatie, p. 251.; Yougoslavie La bataille de l'autoroute Belgrade-Zagreb La Croatie bientôt coupée en deux [Yugoslavia The Battle of the Belgrade-Zagreb Motorway Croatia soon cut in two]. Le Monde, 10 Sep 1991, https://www.lemonde.fr/archives/article/1991/09/10/yougoslavie-la-bataille-de-l-autoroutebelgrade-zagreb-la-croatie-bientot-coupee-en-deux_4040142_1819218.html [Access on January 10, 2022].

${ }^{14}$ HR-HDA-1579., k. 13, 30 Days in Croatia, Croatia and the World, August 1991.; WINLAND, Daphne: We Are Now a Nation: Croats between 'Home and Homeland. Toronto - Buffalo - London, 2014, University of Toronto Press, pp. 55-56; Apel za spas Dubrovnika profesora njemačkih sveučilišta [An appeal for the salvation of Dubrovnik by a professor at a German university]. Politička misao. 1991, vol. 28., no. 4., pp. 72-73.
} 
principles of the Paris Charter for a new Europe had to be respected and that stopping the war was an aim of the Conference. ${ }^{15}$

Intelligence service of EC concluded that Carrington conference was farce and failure that was useful only to Serbian forces that have been using the Conference for ensuring the time for expansionism on Croatia. Great Britain and France were opposing to help or to recognize Croatia and were refusing to impose economic sanctions on Serbia so they were hold accountable for the silent support for the Serbian attacks. ${ }^{16}$

\section{Declaration of the independence and international recognition}

On the last day of moratorium, on $7^{\text {th }}$ October 1991, YNA aircrafts rocketed Banski dvori, the part of the Upper city of Zagreb that presents Croatian political center, with an intention to carry out an assassination attack on Tuđman, Mesić and Marković. The main aim was to prevent Croatia from declaring independence and to disable remains of Yugoslavian institutions in the same time, but politicians avoided the attack by leaving the building just few minutes before. ${ }^{17}$ The moratorium have expired at $8^{\text {th }}$ October 1991, the day when the Croatian Parliament adopted the Decision on the termination of all state legal relations of the Republic of Croatia and other republics and provinces. In that way, Croatia gave up the legitimacy and legacy to all organs of the SFRY and terminated all state and legal ties based on which it formed the former SFRY with other republics and provinces. Croatia did not recognize any legal act of federation organ as valid, but did recognize independence and sovereignty of other republics of former SFRY. Croatia declared a will, based on the principle of the reciprocity, about establishing, maintaining and developing friendly, political, economic, cultural and other relations with the states it is not in the armed conflict.

\footnotetext{
${ }^{15}$ Statement on the occasion of the ceremonial opening of the Conference on Yugoslavia. EPC Bulletin, 1991, vol. 256., p. 392.

${ }^{16}$ HR-HDA-1741., f. 65, Executive Intelligence Review: Recognize Croatia and Slovenia, 19. 9. 1991.

${ }^{17}$ Granić, op. cit. pp. 21-22.; NOBILO, op. cit. p. 116.
} 
Apart of that, as a sovereign and independent state, Croatia declared recognition of all fundamental rights and rights of national minorities mentioned in the General declaration of UN, Final Helsinki act, documents of KESS, and Paris Charter for a new Europe as part of European integrational processes. In addition, Croatia declared the continuation of a procedure for determination of mutual rights and obligations in relation to former federation and other republics of the former SFRY. On the same day, the Croatian Parliament adopted the Conclusions of armed aggression on the Republic of Croatia that clearly shows that Croatia de facto and de iure was in a state of war because of the aggression of the Republic of Serbia and YNA. ${ }^{18}$

Some of the states have recognized Croatia at the end of 1991, but republics of EC have recognized it at $15^{\text {th }}$ January 1992 , the day that the authorities consider as a Day of international recognition of the Republic Croatia. After that, most of other states of the world followed the example and the process of international recognition ended at $22^{\text {nd }}$ May 1992 when Croatia had become an UN member. ${ }^{19}$

\footnotetext{
${ }^{18}$ Narodne novine, br. 53/1991.

${ }^{19}$ Statement on the recognition of Yugoslav republics. EPC Bulletin. 1992, vol. 8., p. 71.
} 